\title{
In Vitro Effects of Cadmium, Zinc and Lead on Calmodulin-Dependent Actions in Oncorhynchus mykiss, Mytilus sp., and Chlamydomonas reinhardtii
}

\author{
Renata Behra \\ EAWAG (Swiss Federal Institute for Water Resources and Water Pollution Control), CH-8600 Duebendorf, Switzerland
}

\begin{abstract}
The potential of cadmium, zinc, and lead to interact with calmodulin $(\mathrm{CaM})$ was investigated by examining in vitro CaM-dependent protein phosphorylation in tissues from rainbow trout (Oncorhynchus mykiss) and sea mussel (Mytilus sp.) and CaM-dependent phosphodiesterase (PDE) activation by algal (Chlamydomonas reinhardtii) extracts. Cadmium, zinc, and lead proved effective in sustaining CaM-dependent protein phosphorylation in systems containing calcium, whereas only lead was capable of CaM activation in systems depleted of calcium. Cadmium lead to a small activation of CaM-dependent PDE activity by algal extracts, corresponding to $\sim 25 \%$ of that induced by calcium. Cadmium-induced PDE-activation could be attributed to the residual calcium present in the extract. The results indicate that metal-induced CaM activation is primarily mediated in the case of cadmium and zinc by resulting calcium/CaM complexes and in the case of lead by lead/ CaM complexes.
\end{abstract}

Heavy metals are widely distributed environmental pollutants, shown in laboratory and field experiments to be toxic to most forms of life (Nordberg et al. 1978; Förstner and Wittman 1981). Their effects on health are very diverse including neurological, cardiovascular, bronchial and renal as well as other disorders (Dreisbach 1983). Intensive toxicological and biochemical research has led to the identification of a large number of cellular targets for essential and toxic metals (Viarengo 1985). The relationships between the binding of various metals to proteins and other targets and the actual biochemical mechanisms leading to toxicity are still unknown. However, in many biological systems some deleterious effects have been linked to an alteration of cellular processes mediated by calcium and to an upsetting of calcium metabolism (Jones and Fowler 1980; Simons 1986).

A hypothesis concerning the basis for metal-induced toxicological effects involves calmodulin (CaM) as a primary intracellular target (Cheung 1984). CaM, a ubiquitous calciumbinding protein, regulates many cellular processes and stimulates the activity of several target proteins (Cheung 1980; Klee and Vanaman 1982). Its action is dependent on the presence of calcium and is mediated through the binding of the $\mathrm{Ca}^{2+}-\mathrm{CaM}$ complex to the respective proteins. The potential role of $\mathrm{CaM}$ in metal toxicity rests upon the finding that, besides calcium, other metals are capable of binding to CaM (Habermann et al. 1983; Chao et al. 1984) and to activate CaM-dependent enzymes (see for example Mazzei et al. 1984; Suzuki et al. 1985; Flik et al. 1987).

So far, only a few studies comment on the potential of metals to interact with CaM from aquatic organisms (Verbost et al. 1988; Lewis et al. 1990; Behra and Gall 1991). Previously we showed that cadmium was effective in stimulating soluble CaM-dependent phosphorylations in cultured fish cells. This paper deals with the interaction of cadmium, lead and zinc with CaM from various tissues of rainbow trout and mussels and from algae. In vitro effects of the metals on CaM-dependent protein phosphorylation and phosphodiesterase activity are examined. A comparative approach, using species widely used for studies in aquatic toxicology, was applied with the goal to identify general principles that govern the interactions of metals with aquatic organisms.

\section{Materials and Methods}

\section{Chemicals}

Leupeptin, pepstatin A and phenylmethanesulfonylfluoride (PMSF) were obtained from Serva (Heidelberg, FRG); trifluoperazine and tosyl-L-phenylalanin-chlormethylketon (TPCK) were obtained from Fluka Chemie (Buchs, Switzerland). Calmidazolium was a gift of J. Krebs, Institut für Biochemie (ETH, Zürich); calmodulin and calmodulin-deficient 3 ', 5 '-cyclic nucleotide phosphodiesterase were from Sigma, division of Fluka Chemie (Buchs, Switzerland); adenosine deaminase and alkaline phosphatase (both calmodulin-deficient) were from Boehringer (Rotkreuz, Switzerland). Amersham (Zürich, Switzerland) provided $\left[\gamma^{32} \mathrm{P}\right]$-ATP $(5000 \mathrm{Ci} / \mathrm{mmol})$. Molecular weight markers were from Bio-Rad Laboratories (Glattbrugg, Switzerland).

\section{Preparation of Fish Tissues}

Rainbow trout, Oncorhynchus mykiss, weighing $\sim 250 \mathrm{~g}$ each, were obtained from a local commercial hatchery. Fish were killed with a blow on the head. Liver, kidney and heart were removed, washed several times in ice-cold isolation medium $(150 \mathrm{mM} \mathrm{KCl}, 1 \mathrm{mM}$ EGTA, $50 \mathrm{mM}$ Tris nitrate, $\mathrm{pH} 7.6$ ), blotted, frozen with liquid nitro- 
gen and stored at $-80^{\circ} \mathrm{C}$. For preparation of cytosol fractions, the tissues were thawed on ice, resuspended in homogenization medium (150 mM KCl, $1 \mathrm{mM}$ PMSF, $10 \mu \mathrm{g} / \mathrm{mL}$ leupeptin, $3 \mu \mathrm{g} / \mathrm{mL}$ pepstatin A, $100 \mu \mathrm{g} / \mathrm{mL}$ TPCK, $50 \mathrm{mM}$ Tris nitrate, $\mathrm{pH} \mathrm{7.6)}$ and finely chopped with scissors. Homogenization was performed by 25 strokes with a Teflon pestle in a Potter Elvehjem homogenizer at 2,000 rpm and $4^{\circ} \mathrm{C}$. Homogenates were centrifuged in a Kontron A 8.24 rotor at $12,000 \mathrm{rpm}$ $\left(12,400 \times g_{\max }\right)$ for $10 \mathrm{~min}$ at $4^{\circ} \mathrm{C}$. The supernatants were further centrifuged in a Kontron TFT 65.13 rotor at 45,000 rpm $\left(185,000 \times g_{\max }\right)$ for 1 h at $4^{\circ} \mathrm{C}$ to yield the cytosolic fractions. This material was stored at $-80^{\circ} \mathrm{C}$ in small aliquots and was thawed only once prior to assay.

\section{Preparation of Mussel Tissues}

Cytosol fractions from the gills and the digestive gland of the mussel Mytilus sp. were prepared in the laboratory of A. Viarengo, Istituto di Fisiologia Generale, Genova. The homogenization medium contained $150 \mathrm{mM} \mathrm{KCl}, 1 \mathrm{mM}$ PMSF, $10 \mu \mathrm{g} / \mathrm{mL}$ leupeptin, $1 \mathrm{mM}$ imidazole, 25 $\mathrm{mM}$ Tris chloride ( $\mathrm{pH} 7.2$ ). Homogenization and centrifugation followed the procedure described for the preparation of fish tissues.

\section{Preparation of Algal Extracts}

Samples of Chlamydomonas reinhardtii (EAWAG 149b), growing in continuous culture in Z-medium (Staub 1961), were obtained from $\mathrm{H}$. Bachmann, EAWAG, Dübendorf.

For the preparation of extracts, cells were pelleted at $5,000 \mathrm{rpm}$ $(3000 \times g)$, washed twice with homogenization buffer $(50 \mathrm{mM}$ Tris nitrate, pH 7.6, containing $1 \mathrm{mM} \mathrm{PMSF}$ and $10 \mu \mathrm{g} / \mathrm{mL}$ leupeptin) and resuspended in two volumes of the same buffer. Homogenization was performed as described above for processing of the fish tissues. After homogenization the extract was frozen in liquid nitrogen and thawed on ice. This procedure was repeated before a second homogenization. The resulting homogenate was centrifuged twice at $8,000 \mathrm{rpm}$ $(7700 \times g)$ to yield the extract.

\section{Protein Phosphorylation}

Endogenous phosphorylation was assayed in a final volume of $50 \mu \mathrm{L}$ containing $50 \mathrm{mM}$ Tris nitrate ( $\mathrm{pH} 7.6), 2 \mathrm{mM} \mathrm{MgCl}_{2}, 40-80 \mu \mathrm{g}$ of cytosolic proteins, $220 \mu \mathrm{M}\left[\gamma^{-32} \mathrm{P}\right]$-ATP (containing l-2 $\mu \mathrm{Ci}$ ), $1 \mu \mathrm{g}$ $\mathrm{CaM}$ where indicated and various concentrations of EGTA, $\mathrm{Ca}$ (II), and metals. Time and temperature were optimized for maximal ${ }^{32} \mathrm{P}$-incorporation. Assays were preincubated for $30 \mathrm{sec}$ at $30^{\circ} \mathrm{C}$, and the reaction was initiated by the addition of $\left[\gamma_{-}{ }^{32} \mathrm{P}\right]-\mathrm{ATP}$. After incubation for 1 min, the reaction was terminated by adding $30 \mu \mathrm{L}$ of sample buffer (Lämmli, 1970) for sodium dodecyl sulfate-polyacrylmide gel electrophoresis (SDS-PAGE) and heating in a boiling water bath for $5 \mathrm{~min}$. Samples were then analyzed by SDS-PAGE on $12.5 \%$ slab gels and autoradiography. Molecular weights on SDS gels were calibrated using phosphorylase b $\left(M_{r} 97,400\right)$, bovine serum albumin $\left(M_{r} 66,200\right)$, ovalbumin $\left(M_{r} 45,000\right)$, carbonic anhydrase $\left(M_{r} 31,000\right)$, soybean trypsin inhibitor $\left(M_{r} 21,500\right)$, and lysozyme $\left(M_{r}[4,400)\right.$ as standards. Proteins were dyed with Coomassie Brillant Blue R250. Autoradiography was performed on Kodak Xomat AR films, with or without Cronex Lightning Plus intensifying screen (Dupont Instruments) for 1-3 days at $-80^{\circ} \mathrm{C}$. Phosphorylation experiments were repeated at least three times.

\section{Measurement of Phosphodiesterase Activity}

The ability of the Chlamydomonas extract to activate CaM-deficient cyclic nucleotide PDE from bovine heart was monitored spectrophoto- metrically by the coupled enzyme assay described by Schiefer (1986) for $\mathrm{CaM}$ determination, with the following modifications. The assay contained in $500 \mu \mathrm{L}$ final volume $50 \mathrm{mM}$ Tris nitrate $\mathrm{pH} 7.6,1 \mathrm{mU}$ phosphodiesterase, $1 \mathrm{U}$ adenosine deaminase, $6 \mathrm{U}$ alkaline phosphatase, various concentrations of $\mathrm{Ca}(\mathrm{II})$ or $\mathrm{Cd}(\mathrm{II})$ in presence of 10 $\mu \mathrm{M}$ EGTA and $75 \mu \mathrm{g}$ of algal protein. All reagent and enzyme solutions were depleted from calcium as described below. In this way, the final total $\mathrm{Ca}$ (II) concentration in the assay was $\sim 2 \mu \mathrm{M}$. Data were statistically analyzed by the Mann-Whitney U-test. Statistical significance was accepted for $p<0.05$.

\section{Miscellaneous}

Protein concentration was determined by the method of Bradford (1976), using the Bio-Rad Protein Assay Reagent and bovine serum albumin as a standard. The $\mathrm{CaM}$ content in the various tissues was determined as described earlier (Behra and Gall 1991).

The concentrations of the free metal ion species (mentioned in the Results and in Discussion sections) were estimated by speciation calculations taking into consideration complexes with defined ligands, as present at the various conditions. Calculations were computed with the Mac-MicroQL-program (Westall 1979). Stability constants of the ligands EGTA, 2-mercaptoethanol and chloride for the different metals were obtained from Smith and Martell (1975) and those of ATP from Sillen and Martell (1971) and Verbost et al. (1988). Stock solutions of metals were prepared from the chloride salts of $\mathrm{Ca}(\mathrm{II}), \mathrm{Cd}(\mathrm{II})$ and $\mathrm{Zn}$ (II) and from the nitrate salts of $\mathrm{Pb}$ (II).

In order to keep calcium contamination low, glassware and plasticware were rinsed with $5 \mathrm{mM}$ EDTA and then exhaustively with double-distilled water. Dyalisis tubing (Visking, Chemie Brunschwig AG, Basel, Switzerland) was successively boiled in (1) deionized water, (2) $0.5 \% \mathrm{NaHCO}_{3}$, (3) five changes of double-distilled water treated with Chelex-100, and (4) two changes in $5 \mathrm{mM}$ EDTA. The tubing was stored in $5 \mathrm{mM}$ EDTA, pH 7.6, 0.2\% sodium azide at $4^{\circ} \mathrm{C}$. Before use, the tubing was rinsed several times with bidistilled water.

For calcium depletion, buffers, reagents and enzymes were passed through small Chelex-100 columns, whereas the various cytosol fractions and the algal extract were incubated overnight with Chelex-100 suspended in $50 \mathrm{mM}$ Tris nitrate, $\mathrm{pH}$ 7.6. Calcium concentrations were measured with an atomic absorption spectrometer (Perkin Elmer 5000).

\section{Results}

\section{Calcium and Calmodulin-Dependent Phosphorylations and Effects of Cadmium}

The patterns of phosphorylation of endogenous proteins in soluble fractions of various rainbow trout tissues are shown in Figure I. In a typical experiment $\mathrm{Ca}^{2+} / \mathrm{CaM}$-dependent phosphorylations were identified by comparison of phosphorylation patterns obtained in presence of $\mathrm{Ca}(\mathrm{II})$ and with no further additions, EGTA or a CaM antagonist. In that way, in the heart cytosol, at least seven protein bands with molecular weights of $\sim 28,43,44,56,58,60$, and $64 \mathrm{kDa}$ could be attributed to phosphorylation by $\mathrm{Ca}^{2+} / \mathrm{CaM}$-dependent protein kinases. Phosphorylation of these substrates was not detectable in presence of $1 \mathrm{mM}$ EGTA (Figure 1A, lane 1) but was visible in presence of $0.5 \mathrm{mM} \mathrm{Ca}$ (II) (Figure IA, lane 2) and slightly enhanced by addition of exogenous CaM (Figure IA, lane 3). The pattern of phosphorylation in presence of the $\mathrm{CaM}$ antagonist trifluoperazine (TFP; Figure 1A, lane 4) corresponded to that with EGTA, indicating the mediation of $\mathrm{CaM}$ in supporting 


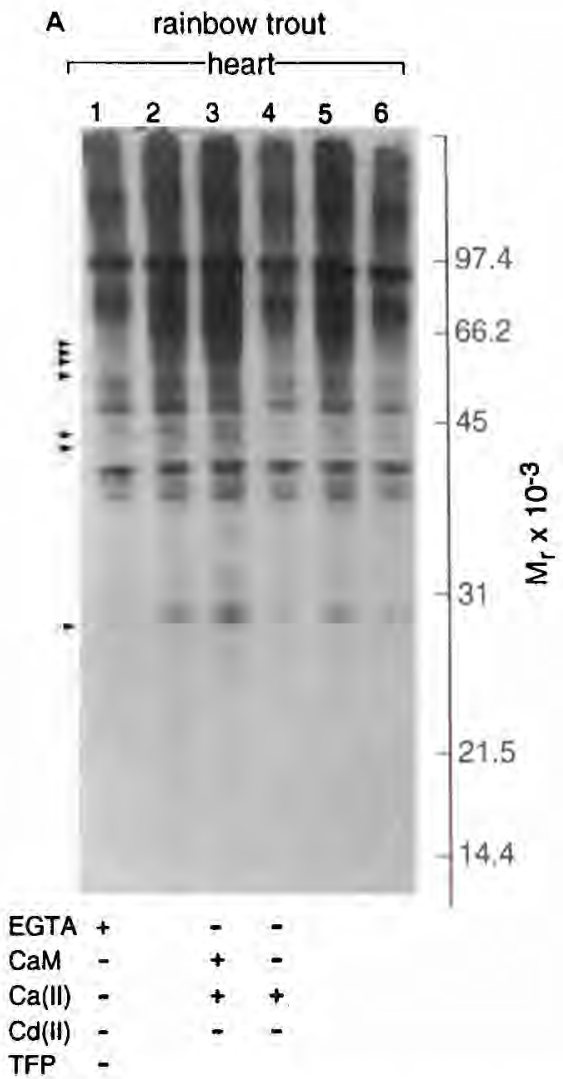

Fig. 1. Autoradiographs showing soluble phosphorylation in rainbow trout using: (A) $60 \mu \mathrm{g}$ heart; (B) $50 \mu \mathrm{g}$ liver; (C) $43 \mu \mathrm{g}$ kidney proteins. Samples were assayed with the following additions: $1 \mathrm{mM}$ EGTA (A, lane 1); $0.5 \mathrm{mM} \mathrm{Ca(II)} \mathrm{(A,} \mathrm{B,} \mathrm{C,} \mathrm{lane} \mathrm{2);} 0.5 \mathrm{mM} \mathrm{Ca(II)}$ and $1 \mu \mathrm{g} \mathrm{CaM}$ (A, lane 3); $0.5 \mathrm{mM} \mathrm{Ca}$ (II) and $20 \mu \mathrm{M}$ TFP (A, lane 4; $\mathrm{B}, \mathrm{C}$, lane 1$) ; 10 \mu \mathrm{M}$ EGTA and $50 \mu \mathrm{M} \mathrm{Cd}(\mathrm{II}),\left(\sim 6 \mu \mathrm{M} \mathrm{Cd}^{2+} ; \mathrm{A}\right.$, lane 5; B, C, lane 3); $10 \mu \mathrm{M}$ EGTA, $50 \mu \mathrm{M}$ Cd(II) and $20 \mu \mathrm{M}$ TFP $(\sim 6$ $\mu \mathrm{M} \mathrm{Cd}^{2+} ; \mathrm{A}$, lane 6 ; $\mathrm{B}, \mathrm{C}$, lane 4$)$. Total $\mathrm{Ca}($ II) concentration in

the observed $\mathrm{Ca}^{2+}$-dependent phosphorylations. In kidney fractions (Figure $1 \mathrm{C}$ ), a protein of $\mathrm{M}_{\mathrm{r}} \sim 45 \mathrm{kDa}$ was apparently the sole substrate phosphorylated in a $\mathrm{Ca}^{2+} / \mathrm{CaM}$-dependent manner, whereas in liver cytosol (Figure 1B) at least five proteins with $M_{r} \sim 23,34,38,45$, and $62 \mathrm{kDa}$ were found to be dependent on $\mathrm{Ca}^{2+}$ and $\mathrm{CaM}$ for phosphorylation. All these substrates were found to be phosphorylated in presence of $0.5 \mathrm{mM}$ $\mathrm{Ca}$ (II) (Figures $1 \mathrm{~B}$ and $\mathrm{C}$, lane 2) but not upon addition of both, $\mathrm{Ca}$ (II) and TFP (Figures $1 \mathrm{~B}$ and $\mathrm{C}$, lane 1).

In all examined tissues CaM-dependent protein phosphorylation was triggered also upon addition of $50 \mu \mathrm{M} \mathrm{Cd}(\mathrm{II})$ and 10 $\mu \mathrm{M}$ EGTA, the resulting calculated $\mathrm{Cd}^{2+}$ concentration being $\sim 6 \mu \mathrm{M}$ (Figure 1A, lane 5; Figures 1B, C, lane 3). Phosphorylation the same substrates was absent by concomitant addition of Cd(II) and TFP (Figure 1A, lane 6; Figures 1B, C, lane 4). Phosphorylation patterns obtained in presence of $\mathrm{Cd}$ (II) were indistinguishable from those observed in presence of $\mathrm{Ca}$ (II) alone.

Phosphorylation of soluble proteins from tissues of the sea mussel (Figure 2 ) revealed only one protein from the digestive gland as substrate of $\mathrm{Ca}^{2+} / \mathrm{CaM}$-dependent kinases. As such, this protein of $\mathrm{M}_{\mathrm{r}} \sim 47 \mathrm{kDa}$ was phosphorylated in presence of $0.5 \mathrm{mM} \mathrm{Ca}$ (II) but not after addition of $1 \mathrm{mM}$ EGTA or TFP (Figure 2B, lanes 2, 1 and 3, respectively). This protein was

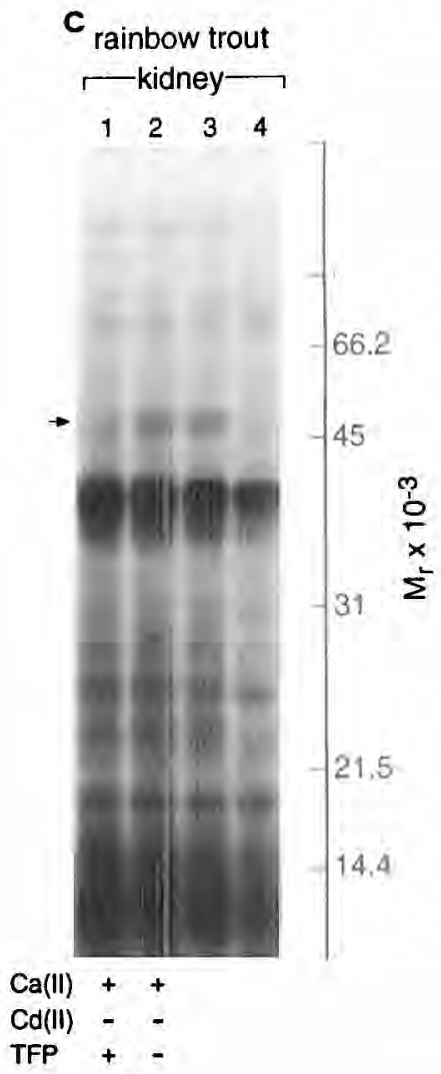

assays without addition of exogenous $\mathrm{Ca}$ (II) was: heart 11; liver, 9; kidney $6 \mu \mathrm{M}$. Endogenous CaM content in assays without addition of exogenous CaM was: heart $\sim 40$; liver, $\sim 100$; kidney $\sim 150 \mathrm{ng} . \mathrm{M}_{\mathrm{r}}$ of major substrates for $\mathrm{Ca}^{2+} / \mathrm{CaM}$-dependent protein kinases are indicated by arrows. Their corresponding $M_{r}$ are: heart, $\sim 28,43,44,56$, 58,60 , and $64 \mathrm{kDa}$, liver $\sim 23,34,38,45$, and $62 \mathrm{kDa}$, kidney, $\sim 45$ $\mathrm{kDa}$

found to be phosphorylated at calculated $\sim 6 \mu \mathrm{M} \mathrm{Cd}^{2+}$ upon addition of $50 \mu \mathrm{M} \mathrm{Cd}(\mathrm{II})$ and $10 \mu \mathrm{M}$ EGTA to the phosphorylation mixture (Figure 2, lane 4); phosphorylation of the same protein was blocked in presence of Cd(II) and TFP (Figure 2, lane 5).

Examination of the phosphorylation patterns of soluble sea mussel proteins further showed one protein of $\mathrm{M}_{\mathrm{r}} \sim 33 \mathrm{kDa}$ from the gills and two proteins of $M_{r} \sim 35$ and $36 \mathrm{kDa}$ from the digestive gland. Their phosphorylation was prevented by TFP but not by EGTA (Figure $2 \mathrm{~A}$ and B, lanes 3 and 1, respectively). The involvement of CaM was confirmed by the observation that phosphorylation of the three proteins was also blocked by $1 \mu \mathrm{M}$ calmidazolium (not shown), a potent CaM antagonist (Van Belle 1981).

Phosphorylation experiments with the algal extract were not indicative of $\mathrm{Ca}^{2+} / \mathrm{CaM}$-dependent protein kinase activities.

\section{Effects of Cadmium, Zinc and Lead on $\mathrm{Ca}^{2+} / \mathrm{CaM}$-Dependent Phosphorylations in Calcium-Depleted Systems}

The observed $\mathrm{Cd}^{2+}$-induced CaM-dependent phosphorylation activities may be due to a direct interaction of the metal with 
A

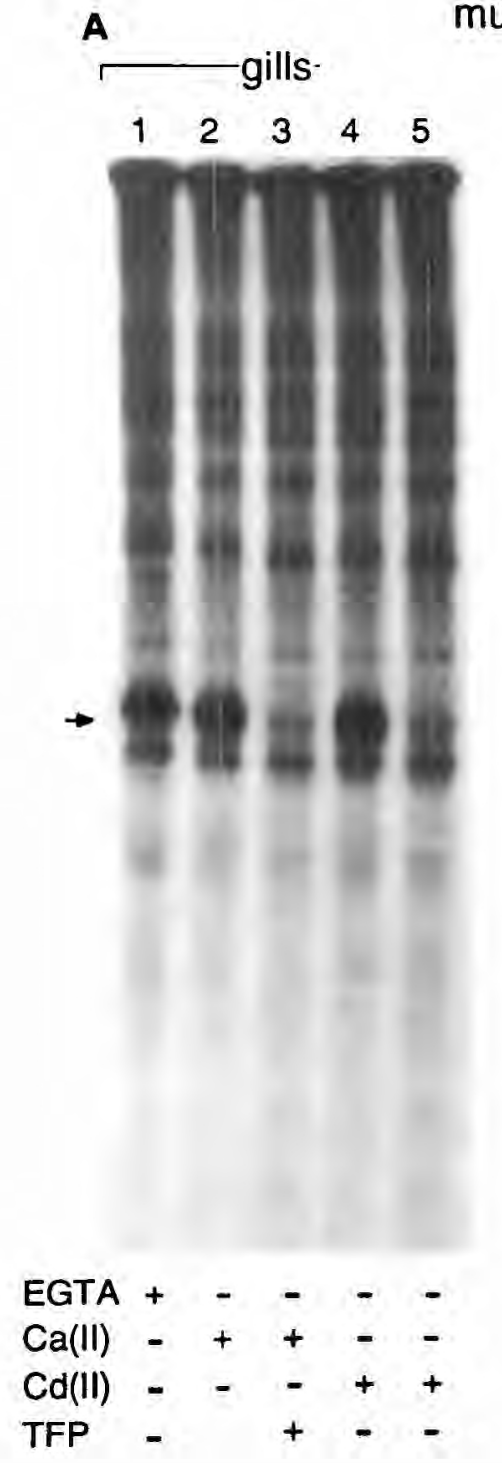

mussels
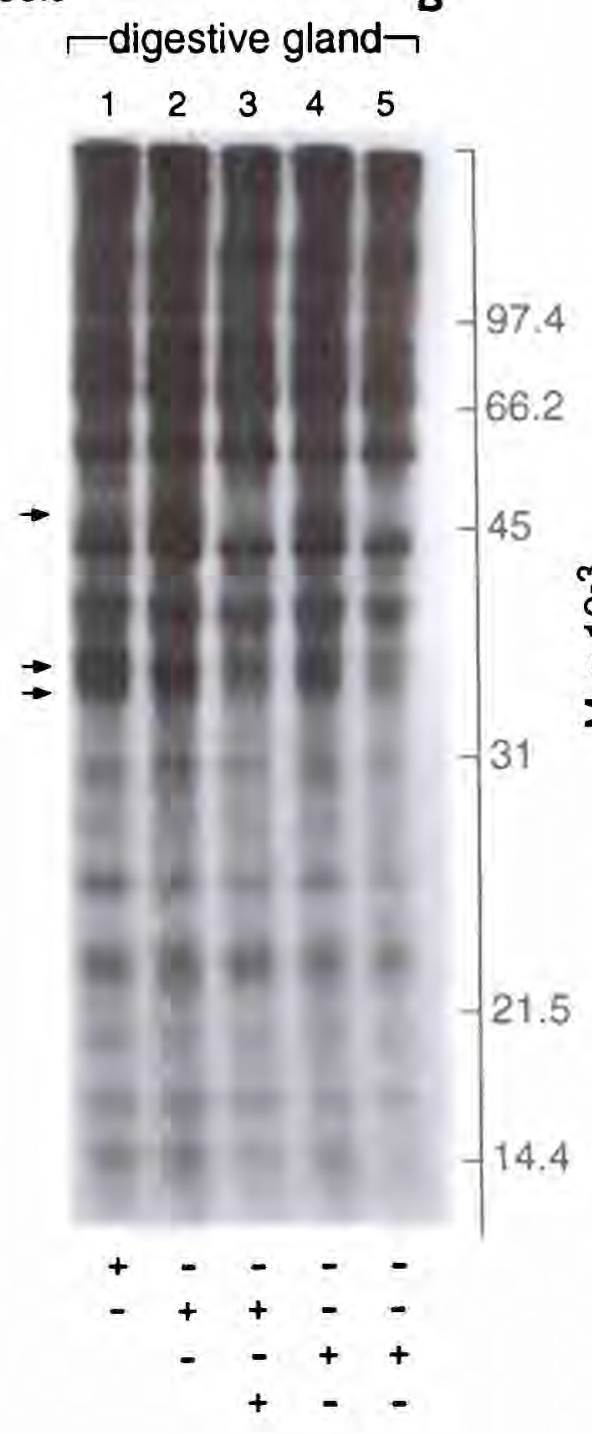

$?$
0
$x$
$\Sigma$

Fig. 2. Autoradiographs illustrating phosphorylation of cytosolic mussel proteins (80 $\mu \mathrm{g}$ each) from: (A) gills; (B) digestive gland. Samples were assayed in presence of $1 \mathrm{mM}$ EGTA (lane 1); $0.5 \mathrm{mM} \mathrm{Ca(II)} \mathrm{(lane} \mathrm{2);} 0.5$ $\mathrm{mM} \mathrm{Ca}$ (II) and $20 \mu \mathrm{M}$ TFP (lane 3); $10 \mu \mathrm{M}$ EGTA and $50 \mu \mathrm{M} \mathrm{Cd}(\mathrm{II}),\left(\sim 6 \mu \mathrm{M} \mathrm{Cd}^{2+}\right.$; lane 4); $10 \mu \mathrm{M}$ EGTA, $50 \mu \mathrm{M} \mathrm{Cd}($ II) and 20 $\mu \mathrm{M}$ TFP $\left(\sim 6 \mu \mathrm{M} \mathrm{Cd} d^{2+} ;\right.$ lane 5). Total Ca(II) concentration in assays without addition of exogenous $\mathrm{Ca}$ (II) was: gills, 20 and digestive gland, $15 \mu \mathrm{M}$. Endogenous $\mathrm{CaM}$ content in assays without addition of exogenous $\mathrm{CaM}$ was: gills and digestive gland, $\sim 300 \mathrm{ng}$ each. Arrows indicate proteins discussed. The corresponding $\mathrm{M}_{\mathrm{r}}$ are: gills, $\sim 33 \mathrm{kDa}$, digestive glands, $\sim 47, \sim 35$, and $36 \mathrm{kDa}$
CaM or to an indirect activation through displacement of $\mathrm{Ca}^{2+}$ from other cytosolic $\mathrm{Ca}^{2+}$-binding sites to $\mathrm{CaM}$. In order to distinguish between these mechanisms, phosphorylations were further examined in systems previously depleted of endogenous $\mathrm{Ca}$ (II). Treatment of the various cytosols with Chelex-100 lowered the endogenous $\mathrm{Ca}^{2+}$ content so that activation of CaMdependent phosphorylation became dependent on the addition of $\mathrm{Ca}$ (II). As shown in Figure 3 for the liver extract, CaMdependent phosphorylation was minimal at the residual total $\mathrm{Ca}$ (II) $\sim 1 \mu \mathrm{M}$, increased upon addition of $\mathrm{Ca}$ (II) and was maximal at a $\mathrm{Ca}^{2+}$ concentration of $\sim 10 \mu \mathrm{M}$ (Figure 3 , lanes $1-4)$. Compared to the phosphorylation pattern obtained at the residual $\mathrm{Ca}^{2+}$ concentration, (Figure 3, lane 1), additions of $\mathrm{Cd}$ (II) or $\mathrm{Zn}$ (II) did not enhance ${ }^{32} \mathrm{P}$-incorporation into substrates of $\mathrm{Ca}^{2+} / \mathrm{CaM}$-dependent protein kinases. In presence of $10 \mu \mathrm{M}$ EGTA and at concentrations as high as $100 \mu \mathrm{M} \mathrm{Cd}$ (II) and 30 or $50 \mu \mathrm{M} \mathrm{Zn(II)} \mathrm{(corresponding} \mathrm{to} \mathrm{calculated} \mathrm{free} \mathrm{ion}$ concentrations of $\sim 14 \mu \mathrm{MCd}^{2+}$ and $\sim 18 \mu \mathrm{M}$ or $\sim 35 \mu \mathrm{M}$ $\mathrm{Zn}^{2+}$ ), both metals inhibited the CaM-dependent as well as other cytosolic phosphorylation activities (Figure 3, lanes 5, 10 , and 11). Both metals showed to be ineffective in stimulat- ing CaM-dependent phosphorylations also in all other previously mentioned $\mathrm{Ca}^{2+}$-limited cytosols (not shown).

Contrary to $\mathrm{Cd}^{2+}$ and $\mathrm{Zn}^{2+}, \mathrm{Pb}^{2+}$ proved very efficient in triggering CaM-dependent phosphorylations in the $\mathrm{Ca}^{2+}-\mathrm{lim}$ ited liver cytosol; the $\mathrm{Pb}^{2+}$-induced phosphorylation activity was blocked by TFP (Figure 3, lanes 6-9). At the lowest tested $\mathrm{Pb}$ (II) concentration of $50 \mu \mathrm{M}$ and in presence of $10 \mu \mathrm{M}$ EGTA (corresponding to a calculated $\mathrm{Pb}^{2+}$ concentration of $\sim 11$ $\mu \mathrm{M}),{ }^{32} \mathrm{P}$-incorporation into substrates of $\mathrm{CaM}$-dependent protein kinases was higher than that at the corresponding $\mathrm{Ca}^{2+}$ concentration (Figure 3 , lanes 6 and 3 ). The minimal requirement of $\mathrm{Pb}^{2+}$ for activation of $\mathrm{CaM}$ was not established. $\mathrm{Pb}^{2+}$ was found to mimic $\mathrm{Ca}^{2+}$ in activating $\mathrm{CaM}$ also in $\mathrm{Ca}$ (II) depleted cytosols from the heart and kidney of rainbow trout and from the digestive gland of mussels (not shown).

\section{Effects of Cadmium on Activation of Phosphodiesterase by Calmodulin from Chlamydomonas}

In order to examine the interaction of heavy metals with Chlamydomonas $\mathrm{CaM}$, the activity of CaM-deficient cyclic 


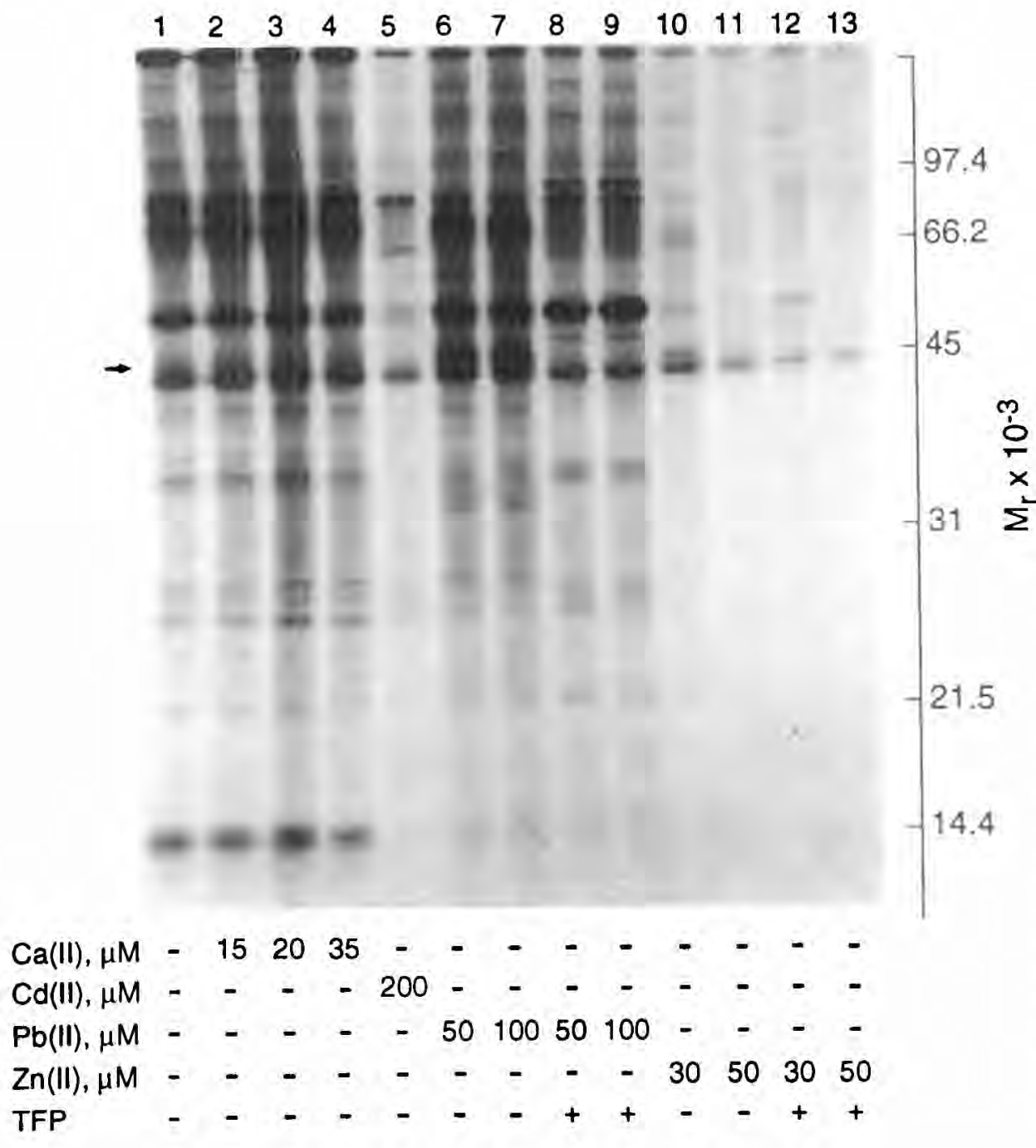

Fig. 3. Autoradiograph showing effects of cadmium, lead and zinc on phosphorylation of cytosolic liver proteins from rainbow trout after depletion of calcium. Samples were assayed directly (lane 1) or in presence of $10 \mu \mathrm{M}$ EGTA (lanes 2-13) and the following additions: 15,20 , and $35 \mu \mathrm{M}$ $\mathrm{Ca}$ (II) $\left(5,10\right.$, and $25 \mu \mathrm{M} \mathrm{Ca}^{2+}$; lanes $2-4$, respectively); $100 \mu \mathrm{M}$ Cd(II) $\left(\sim 14 \mu \mathrm{M} \mathrm{Cd}^{2+}\right.$, lane 5); 50 and $100 \mu \mathrm{M} \mathrm{Pb}$ (II) $(\sim 11$ and $\sim 26$ $\mu \mathrm{M} \mathrm{Pb}^{2+}$, respectively) in absence (lanes 6,7 ) or in presence of 20 $\mu \mathrm{M}$ TFP (lanes 8,9 ); 30 and 50 $\mu \mathrm{M} \mathrm{Zn}$ (II) $(\sim 18$ and $\sim 35 \mu \mathrm{M}$ $\mathrm{Zn}^{2+}$, respectively) in absence (lanes 10,11 ) or in presence of 20 $\mu \mathrm{M}$ TFP (lanes 12, 13). Residual total $\mathrm{Ca}$ (II) concentration in assays without addition of exogenous $\mathrm{Ca}$ (II) was $\sim 1 \mu \mathrm{M}$. The arrow indicates one major substrate for $\mathrm{Ca}^{2+} / \mathrm{CaM}-$ dependent protein $\mathrm{ki}-$ nases with $\mathrm{M}_{\mathrm{r}}$ of $\sim 45 \mathrm{kDa}$

nucleotide phosphodiesterase (PDE) from bovine heart was assayed with the algal extract as source of $\mathrm{CaM}$ and previously depleted of $\mathrm{Ca}$ (II) and in presence of various amounts of $\mathrm{Ca}^{2+}$ or $\mathrm{Cd}^{2+}$. As shown in Figure 4, activation of PDE by the algal extract was dependent on the addition of exogenous $\mathrm{Ca}$ (II), half-maximal stimulation occuring at $\sim 10 \mu \mathrm{M} \mathrm{Ca}{ }^{2+}$. Also depicted in Figure 4 is the effect of $\mathrm{Cd}^{2+}$ on both basal and CaM-dependent PDE activity. Addition of Cd(II) actually led to a weak but significant stimulation of CaM-dependent PDE activity. Maximal activity $(14.76 \mathrm{nmol} / \mathrm{mL} / \mathrm{min} ;$ S.D. $=0.33$; $\mathrm{N}=6$ ) corresponded to $\sim 25 \%$ of that induced by $\mathrm{Ca}^{2+}$ and occurred at $\sim 7.5 \mu \mathrm{M} \mathrm{Cd}^{2+}$ upon addition of $20 \mu \mathrm{M} \mathrm{Cd}$ (II) and $10 \mu$ M EGTA. CaM-dependent PDE activity decreased gradually and significantly $(\mathrm{p}<0.05)$ compared to the basal activity, at concentrations higher than $7.5 \mu \mathrm{M} \mathrm{Cd}^{2+}$. Inhibition of basal PDE activity was observable at $\mathrm{Cd}^{2+}$ concentrations higher than $100 \mu \mathrm{M} \mathrm{Cd}^{2+}$. The effects of $\mathrm{Pb}^{2+}$ on algal $\mathrm{CaM}$ could not be examined because concentrations as low as $1 \mu \mathrm{M} \mathrm{Pb}^{2+}$ proved already inhibitory on basal PDE activity.

\section{Discussion}

The studies reported here were undertaken in order to examine possible interactions between some metals of toxicological in- terest and $\mathrm{CaM}$ from various aquatic organisms. For this purpose tissues of the rainbow trout and sea mussel and algal extracts were first characterized with respect to soluble CaMdependent protein phosphorylations and activation of cyclic nucleotide PDE.

The results of this investigation indicate that $\mathrm{CaM}$-dependent protein phosphorylation is a common feature of rainbow trout tissues. The highest CaM-dependent kinase activity was observed in the heart tissue, followed by that in the liver, whereas only one substrate could be identified in the kidney. In a previous study we have characterized soluble CaM-dependent phosphorylations in a rainbow trout gonadal cell line and found a very high phosphorylation activity (Behra and Gall 1991). Although the cell line was shown to have a high content of CaM, the CaM-dependent kinase activities described in the present study apparently do not correlate with the CaM content of the various tissues, the highest soluble $\mathrm{CaM}$ concentration having been found in the kidney. On the basis of a molecular weight comparison no common cytosolic substrate for $\mathrm{CaM}$-dependent protein kinases could be found.

Examination of mussel tissues led to the identification of only one substrate of CaM-dependent protein kinases in the digestive gland. Although not directly relevant in the context of this study one additional observation is worth making. Two 


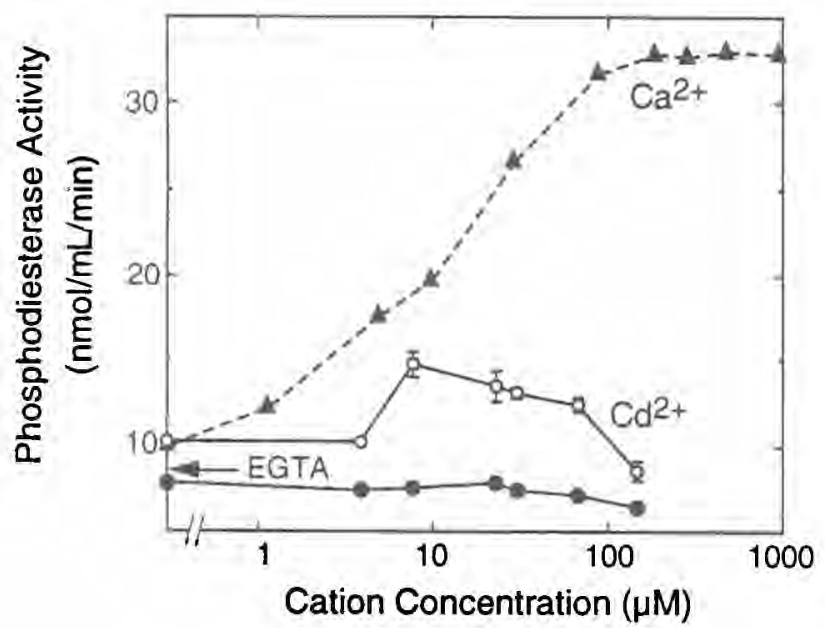

Fig. 4. Effect of $\mathrm{Ca}^{2+}$ and $\mathrm{Cd}^{2+}$ on PDE activation by algal extracts depleted of endogenous calcium. Metals were tested in presence of 10 $\mu \mathrm{M}$ EGTA. Added metal and calculated free metal concentrations were: $11,20,40,100,200,300,500$ and $1000 \mu \mathrm{M} \mathrm{Ca}($ II) , corresponding to $\sim 1.1,9.6,28.9,86.7,183,279,472$ and $954 \mu \mathrm{M} \mathrm{Ca}^{2+}$ or 15 , $20,40,50,100$ and $200 \mu \mathrm{M} \mathrm{Cd}$ (II), corresponding to $\sim 3.8,7.6,22.8$, 30,68 and $145 \mu \mathrm{M} \mathrm{Cd}{ }^{2+}$. The calculated free ion concentration of each cation is indicated in the abscissa. Effect of cadmium on basal PDE activity in absence of algal extract is indicated by open circles. Bars represent \pm 1.96 standard error $(95 \%$ confidence interval; $\mathrm{N}=6$ ). The arrow shows the basal activity in presence of algal extract and $1 \mathrm{mM}$ EGTA. Residual total $\mathrm{Ca}(\mathrm{II})$ concentration in samples without addition of exogenous $\mathrm{Ca}(\mathrm{II})$ was $2 \pm 0.25 \mu \mathrm{M}$

additional proteins from the digestive gland, as well as one protein from the gills, were unexpectedly found to be phosphorylated in the presence of EGTA or Ca(II) but not in presence of the CaM antagonists TFP or calmidazolium. These results, together with only few other reports (Geiser 1991 and references cited therein), suggest a calcium-independent function for CaM.

Phosphorylation experiments in the presence of $\mathrm{Cd}^{2+}, \mathrm{Pb}^{2+}$, or $\mathrm{Zn}^{2+}$ showed that in systems containing $\mathrm{Ca}^{2+}$ all metals supported CaM-dependent protein phosphorylations but that, in systems relatively free of $\mathrm{Ca}^{2+}$ contamination, only $\mathrm{Pb}^{2+}$ did. These results demonstrate the potential of $\mathrm{Cd}^{2+}, \mathrm{Pb}^{2+}$, and $\mathrm{Zn}^{2+}$ to trigger $\mathrm{CaM}$ actions, though through different activation mechanisms. Whilst $\mathrm{Pb}^{2+}$ stimulates CaM-dependent reactions through direct binding to $\mathrm{CaM}$, indirect experimental evidence indicates that $\mathrm{Cd}^{2+}$ and $\mathrm{Zn}^{2+}$ act by a mechanism involving displacement of $\mathrm{Ca}^{2+}$ from intracellular binding sites and resulting in $\mathrm{CaM}$ activation through the increase in free calcium ion concentration. Indirect evidence for a rise in intracellular free $\mathrm{Ca}^{2+}$ concentration upon exposure of various cell types to $\mathrm{Cd}^{2+}$ has been reported in other studies (Verbost $e t$ al. 1989 and references cited therein).

Studies of PDE activation by $\mathrm{CaM}$ from algae further supported the mode of $\mathrm{Cd}^{2+}$-induced $\mathrm{CaM}$ activation by a displacement mechanism. Introduction of $\mathrm{Cd}^{2+}$ in the assay induced a weak activation of CaM-dependent PDE. The residual $\mathrm{Ca}$ (II) concentration in the PDE assay system, estimated from $\mathrm{Ca}$ (II) determinations in the algal extract after $\mathrm{Ca}$ (II) depletion to be $\sim 2 \mu \mathrm{M}$, may actually explain the observed PDE activation. Upon addition of Cd(II) displacement of $\mathrm{Ca}^{2+}$ from ligands present in the assay system would result in an increase of free $\mathrm{Ca}^{2+}$ concentration high enough, when compared to PDE activation by $\mathrm{Ca}^{2+}$, to account for the observed PDE activation. According to a $\mathrm{Ca}^{2+}$-displacement mechanism, maximal PDE activity would be dependent on the maximal $\mathrm{Ca}^{2+}$ concentration available for activation. This suggestion is also supported by the fact that concentrations of $\mathrm{Cd}^{2+}$ higher than those leading to maximal PDE activity only led to a progressive inhibitory action. Under these conditions, there is no further increase in free $\mathrm{Ca}^{2+}$ concentration and thus in PDE activity and the inhibitory effects of $\mathrm{Cd}^{2+}$ become visible. Similar mechanisms have been proposed by Verbost et al. (1988) as an explanation of the reported biphasic effect of Cd(II) on PDE (Chao et al. 1984; Suzuki et al. 1985; Flik et al. 1987) and other CaM-dependent enzymes (Mazzei et al. 1984).

In summary, the results from phosphorylation and PDE activation experiments indicate that in presence of cytosolic competing binding sites $\mathrm{Cd}^{2+}$ and $\mathrm{Zn}^{2+}$ have a poor, if any, accessibility to CaM, whereas $\mathrm{Pb}^{2+}$ is apparently available for binding to $\mathrm{CaM}$. The results also indicate that observed $\mathrm{CaM}$ activations are mainly mediated in the case of $\mathrm{Cd}^{2+}$ and $\mathrm{Zn}^{2+}$ by resulting $\mathrm{Ca}^{2+} / \mathrm{CaM}$ complexes and in the case of $\mathrm{Pb}^{2+}$ by $\mathrm{Pb}^{2+} / \mathrm{CaM}$ complexes, thus confirming the suggested involvement of metals in activating CaM-dependent actions (Cheung 1984). This last suggestion was inferred from binding experiments that demonstrated that besides $\mathrm{Ca}^{2+}$ also other metals proved capable to bind to CaM (Chao et al. 1984; Suzuki et al. 1985; Habermann et al. 1983) and that the resulting metal-CaM complexes were efficient in activating CaM-dependent actions (Goldstein and Ar 1983; Mazzei et al. 1984).

The importance of $\mathrm{CaM}$ in mediating the effects of calcium to many different target proteins and as a regulator of many cellular processes (Cheung 1980; Klee and Vanaman 1982) ask for examination of the potential consequences of its activation with respect to metal-induced toxicity. At present, however, such a direct relationship has not been established. In this context it should be considered that $\mathrm{Cd}^{2+}$ and $\mathrm{Pb}^{2+}$ have been recently shown to activate skeletal muscle troponin $\mathrm{C}, \mathrm{a} \mathrm{Ca}^{2+}$. binding protein highly homologous to CaM (Chao 1991) and also that other $\mathrm{Ca}^{2+}$ receptors have been shown to be highly sensitive to heavy metals. Nanomolar concentrations of $\mathrm{Cd}^{2+}$ inhibit branchial $\mathrm{Ca}^{2+}$ uptake (Verbost et al. 1988), and picomolar concentrations of $\mathrm{Pb}^{2+}$ activate protein kinase $\mathrm{C}$ (Markovac and Goldstein 1988).

Determination of the extent to which metals are available to these different targets in vivo awaits further experimental evaluation in order to delineate the biochemical determinants of metal toxicity.

Acknowledgments. I thank G. Genoni and H. Güttinger for their critical reading of the manuscript. I am indebted to A. Viarengo for providing the mussel tissues, to D. Kistler for assistance in measurement of calcium, to H. Bolliger for the artwork and to P. Schlup for the photography.

\section{References}

Behra R, Gall R (1991) Calcium/calmodulin-dependent phosphorylation and the effect of cadmium in cultured fish cells. Comp Biochem Physiol 100C:191-195 
Bradford MM (I976) A rapid method for the quantification of microgram quantities of protein using the principle of dye binding. Anal Biochem 72:248-254

Chao S-H, Suzuki Y, Zysk JR, Cheung WY (1984) Activation of calmodulin by various cations as a function of ionic radius. Mol Pharmacol 26:75-82

Cheung WY (1980) Calmodulin plays a pivotal role in cellular regulation. Science 207:19-27 (1984) Calmodulin: its potential role in cell proliferation and heavy metal toxicity. Federation Proc 43:2995-2999

Dreisbach RH (1983) Handbook of poisoning: prevention, diagnosis and treatment, 11 th ed Lange Medical Publications, Los Altos, CA

Flik G, Van de Winkel JGJ, Pärt P, Wendelaar Bonga SE, Lock RAC (1987) Calmodulin mediated cadmium inhibition of phosphodiesterase activity, in vitro. Arch Toxicol 59:353-359

Förstner U, Wittmann GTW (1981) Metal pollution in the aquatic environment, 2nd revised ed. Springer-Verlag, Berlin

Geiser JR, van Tuinen D, Brockerhoff SE, Neff MM, Davis TN (1991) Can calmodulin function without binding calcium? Cell 65:949 959

Goldstein GW, Ar D (1983) Lead activates calmodulin sensitive processes. Life Sci 33:1001-1006

Habermann E, Crowell K, Janicki P (1983) Lead and other metals can substitute for $\mathrm{Ca}^{2+}$ in calmodulin. Arch Toxicol 54:61-70

Jones HS, Fowler BA (1980) Biological interactions of cadmium with calcium. Ann NY Acad Sci 355:309-318

Klee CB, Vanaman TC (1982) Calmodulin. Adv Protein Chem 35:213-321

Lämmli UK (1970) Cleavage of structural proteins during the assembly of the head of bacteriophage T4. Nature (Lond) 277:680-685

Lewis TL, Yuan Y, Haug A (1990) Calmodulin concentration in mucus of rainbow trout, Salmo gairdneri, exposed to combinations of acid, aluminum, and calcium. Bull Environ Contam Toxicol 44:449-455

Markovac J, Goldstein GW (1988) Picomolar concentrations of lead stimulate brain protein kinase C. Nature (Lond) 334:71-73
Mazzei GJ, Girard PR, Kuo JF (1984) Environmental pollutant $\mathrm{Cd}^{2+}$ biphasically and differentially regulates myosin light chain kinase and phospholipid/ $\mathrm{Ca}^{2+}$-dependent protein kinase. FEBS Lett 173:124-128

Nordberg GF, Fowler BA, Friberg L, Jernelov A, Nelson N, Piscator M, Sanstead HH, Vostal J, Vouk VB (1978) Factors influencing metabolism and toxicity of metals: a consensus report. Environ Health Perspect 25:3-41

Sillen LG, Martell A (1971) Stability constants, Suppl. No. 1, Special Publication 25, The Chemical Society. Burlington House, London

Simons JJB (1986) Cellular interactions between lead and calcium. $\mathrm{Br}$ Med Bull 42:431-434

Smith RM, Martell AE (1975) Critical stability constants, Vol 3. Plenum Press, New York

Staub R (1961) Ernährungsphysiologisch-autökologisch Untersuchungen an der planktischen Blaualge Oscillatoria rubescens. Schw Z Hydro 23:82-198

Suzuki Y, Chao S-H, Zysk JR, Cheung WY (1985) Stimulation of calmodulin by cadmium ion. Arch Toxicol 57:205-211

Van Belle H (1981) R 24571: A potent inhibitor of calmodulin-activated enzymes. Cell Calcium 2:483-493

Verbost PM, Flik G, Lock RAC, Wendelaar Bonga SE (1988) Cadmium inhibits plasma membrane calcium transport. J Membr Biol 102:97-104

Verbost PM, Van Rooij J, Flik G, Lock RAC, Wendelaar Bonga SE (1989) The movement of cadmium through freshwater trout branchial epithelium and its interference with calcium transport. J Exp Biol 145:185-197

Viarengo A (1985) Biochemical effects of trace metals. Mar Pollut Bull 16:153-158

Westall J (1979) MICROQL, a chemical equilibrium program in BASIC, Internal Report. EAWAG, Dübendorf

Manuscript received April 6, 1992 and in revised form August 5, 1992 